\title{
References
}

Dawes, P. R. 1972: Precambrian crystalline rocks and younger sediments of the Thule district, North Greenland, Rapp. Grenlands geol. Unders. 45, 10-15.

Dawes, P. R. 1975: Reconnaissance of the Thule Group and underlying basement rocks between Inglefield Bredning and Melville Bugt, western North Greenland. Rapp. Grønlands geol. Unders. 75, 34-38.

Dawes, P. R. 1979a: Field investigations in the Precambrian terrain of the Thule district, North-West Greenland. Rapp. Grønlands geol. Unders. 95, 14-22.

Dawes, P. R. 1979b: Precambrian and Palaeozoic development of northern Greenland. Norsk Pol. Inst. Skr. 167, 321-324.

Escher, A. 1970: Tectonic/Geological map of Greenland. 1:2 500 000. Copenhagen: Geol. Surv. Greenland.

Escher, J. C. \& Stecher, O. 1978: Precambrian geology of the Upernavik - Red Head region $\left(72^{\circ} 15^{\prime}-75^{\circ} 15^{\prime} \mathrm{N}\right)$, northern West Greenland. Rapp. Gronlands geol. Unders. 90, $23-26$.

Kalsbeek, F., Bridgwater, D. \& Zeck, H. P. 1978: A $1950 \pm 60 \mathrm{Ma}$ Rb-Sr whole-rock isochron age from two Kangâmiut dykes and the timing of the Nagssugtoqidian (Hudsonian) orogeny in West Greenland. Can. J. Earth Sci. 15, 1122-1128.

Larsen, O. \& Dawes, P. R. 1974: K/Ar and Rb/Sr age determinations on Precambrian crystalline rocks in the Inglefield Land - Inglefield Bredning region, Thule district, western North Greenland. Rapp. Grønlands geol. Unders. 66, 5-8.

\section{Preliminary investigations of the Quaternary of Melville Bugt and Dundas, North-West Greenland}

\section{Michael Kelly}

Two weeks were spent in the area shown in fig. 10 in 1978, mainly in northern Melville Bugt, but including a brief visit to sites around Dundas. Sample material from these areas was analysed for ${ }^{14} \mathrm{C}$ and amino acids in 1979 and the results are listed in 'Results'.

\section{Melville Bugt}

There is evidence of glaciation in the form of erratics and isolated till deposits in all the areas visited, including the outermost peninsulas and islands, e.g. Kap York, Bushnan $\varnothing$, Kap Walker, Skene Øer, Sabine Øer. This last occurrence represents an expansion of the Greenland Ice Sheet of at least $40 \mathrm{~km}$. Although the northern localities are near to present day local ice caps, their topographic setting, and the provenence of their erratics in some cases, indicate that an ice sheet has covered this area also. For instance, sandstone erratics of the Thule Group, occurring at over $400 \mathrm{~m}$ on the plateau at Kap York, may have been transported from the zone of Thule Group outcrops to the north by ice filling De Dødes Fjord, which is a deep trough, over $1000 \mathrm{~m}$ deep opposite Kap York.

The distribution of ice at this ice sheet stage of glacierisation suggests that most of the 


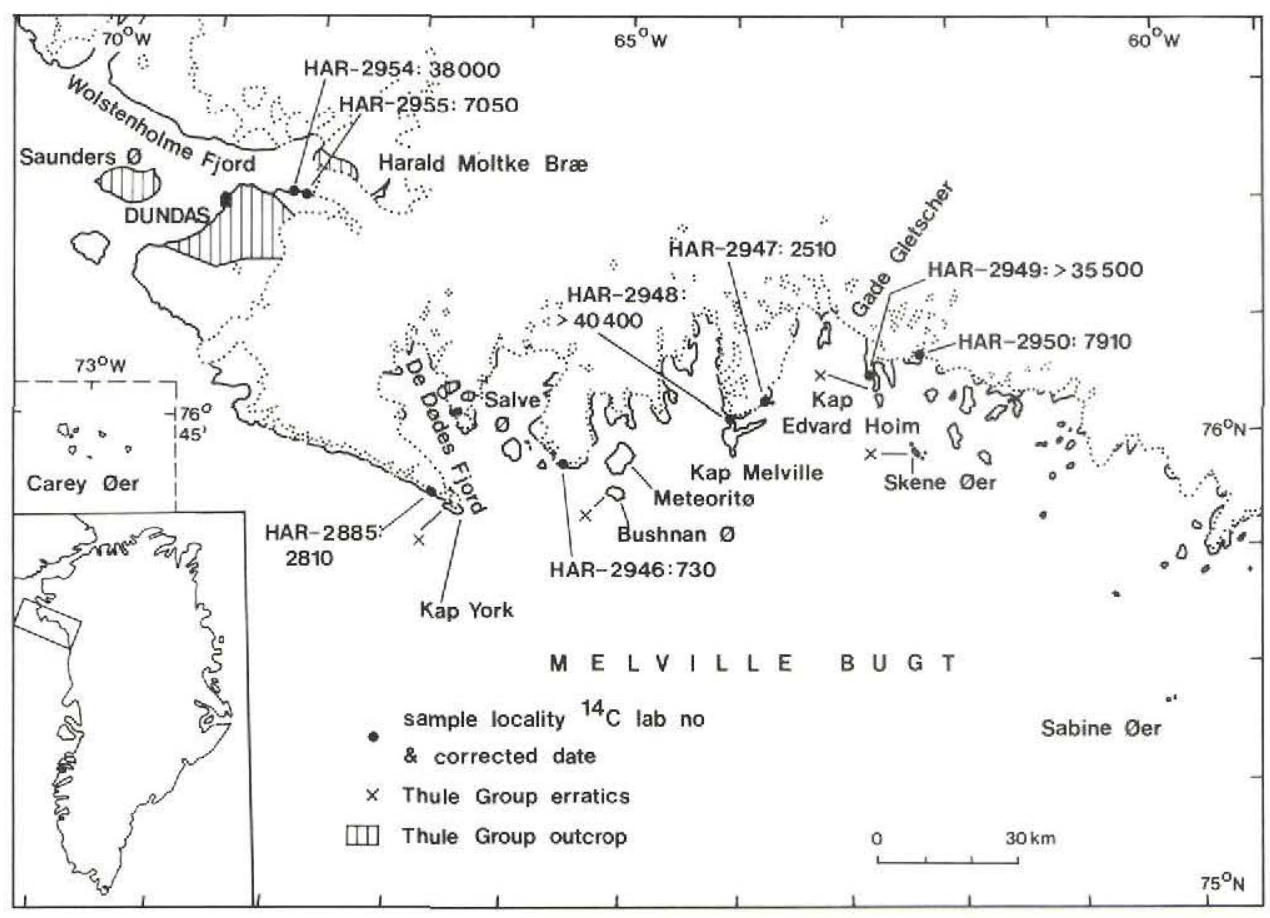

Fig. 10. Locality map with location of dated samples and of Thule Group erratics (Thule Group outcrops from Dawes (1979)).

$20-50 \mathrm{~km}$ wide continental shelf would be glaciated. Some indication of the antiquity of this event is given by the high degree of outcrop weathering in the localities mentioned, with widespread development of autochthonous boulder fields on slopes and flat surfaces.

A younger stage of ice cover, with a margin near the present coast, is represented by scattered lateral moraines on the peninsulas, but it is not yet possible to correlate or relatively date them precisely.

The present ice cover, by the ice sheet and by the series of contiguous ice caps and ice fields which cover most of the western area, expanded in the late Holocene, reaching its maximum in this century.

Marine deposits are very limited in the area. Fossiliferous Holocene marine sediments are known only from reworked material in the late Neoglacial moraines. ${ }^{14} \mathrm{C}$ dates from these range from $730-7910$ B. P. (see Results), which although the faunas could be mixed, probably indicate the general duration of Holocene marine conditions behind the Neoglacial margin. Elsewhere, well defined cobble beaches occurring up to $10-16 \mathrm{~m}$ above sea level are presumably Holocene. A date of 2810 B. P. (HAR-2885) on basal peat on beach gravels close to high water mark gives the minimum age of these beaches and the time when sea level fell to or below its present level. However, it is not yet known whether these beaches represent the Holocene marine limit.

Benches at higher levels, at 30-50 m, fringe several of the islands, e.g. Salve $\varnothing$, Bushnan 
Table 2. Amino acid determinations from the Thule district

\begin{tabular}{lllll}
\hline & \multicolumn{3}{l}{$\begin{array}{l}\text { No. } \\
\text { determ. Total }\end{array}$} & \multicolumn{2}{c}{ d-Allo: I-lsoleucine } \\
& & \multicolumn{2}{l}{ Free } \\
\hline GGU 194471: AAL-1117 Hiatella arctica & 3 & $0.037-0.075$ & $0.31-0.39$ \\
GGU 194478: AAL-1118 Mya truncata & 3 & $0.055-0.056$ & $0.50-0.61$ \\
GGU 194484: AAL-1119 Hiatella arctica & 3 & $0.037-0.051$ & $0.42-0.46$ \\
\hline
\end{tabular}

$\emptyset$, Meteoritø. Typically these are covered with deposits of strongly soliflucted till and frost shattered bedrock in which isolated, or patches of, well rounded cobbles occur (Salve $\varnothing$, Kap Edvard Holm). These features may possibly be of pre-Holocene marine origin.

In situ pre-Holocene marine sediments are known at two localities (Navdlortoq, Kap Melville, and Ivnaqigsorssuaq, Kap Edvard Holm). The shell faunas from both give infinite ${ }^{14} \mathrm{C}$ ages (HAR-2948 and HAR-2949) but amino acid analyses (Table 2) indicate a comparable intra last glaciation age for them (AAL-1117 and AAL-1118). At both localities thin marine sediments are overlain by sediments interpreted as tills. Whilst the first site lies only $1 \mathrm{~km}$ in front of the margin of a local piedmont glacier the second is about $12 \mathrm{~km}$ in front of the Gade Gletscher outlet of the Ice Sheet.

\section{Dundas}

A brief reconnaissance of the area near the southern margin of Harald Moltke Brae confirmed the existence of the well-preserved complex lateral moraine, which was reported by Krinsley (Davies et al., 1963). It lies 200-300 m above the Historical Moraine and the present ice margin. The Historical Moraine itself consists of a lateral moraine at sea level which is rich in reworked marine sands. The shell fragments present, also referred to by Krinsley, are dated to 7050 B. P. (HAR-2955). This indication of the probable occurrence of early Holocene marine sediments behind the ice margin is consistent with previous dates on in situ sediments close to the lateral moraine on the north side of the fjord (9000 B. P., L-216A (Goldthwait, 1960) and 9800 B. P., M-723 (Crane \& Griffin, 1959)).

Two adjacent exposures of fossiliferous sediments occur at sea level just beyond the lateral moraine, consisting of $12 \mathrm{~m}$ of fossiliferous sands and $20 \mathrm{~m}$ of sparsely fossiliferous gravels. The former at least proves to be pre-Holocene, with a ${ }^{14} \mathrm{C}$ age of $>38000 \mathrm{~B}$. $\mathrm{P}$. (HAR-2954) and intra last glaciation amino acid values (AAL-1119), which are broadly comparable with the Melville Bugt ones.

\section{Comment}

It is not yet possible to fit all the data into a definite stratigraphic framework. However, it is helpful to use the approach of Miller \& Andrews (Miller et al., 1977) and regard the marine units as genetically related to the periods of glacial advance and till deposition. Thus the older Melville Bugt marine sediments and overlying tills should represent the isostatic depression and subsequent ice cover of an advance during the last glaciation. This is infor- 
mally named the Kap Melville glacial episode and the deposits at both the Melville Bugt sites and at Wolstenholme Fjord are referred to it.

Since the present temperature, and probably also the thermal history, of the area is not very different from that of Baffin Island the amino acid data from the two areas can be compared. This suggests a possible correlation of the Kap Melville episode with that represented by the Kogaly Member which is considered to date from somewhere between 40000 and 70000 B. P. (Miller et al., 1977), i.e. a broadly mid last glaciation age.

Several other occurrences of marine sediments in the Thule district have yielded infinite ${ }^{14} \mathrm{C}$ dates. At Saunders $\varnothing$ (Davies et al., 1963; Blake, 1975) they lie between two tills and may also correlate with this episode. However, at Olrik Fjord the relationship of the sediments to a glacial advance is uncertain (Weidick, 1978), whilst at Carey Øer (Blake, 1977) they are definitely overlain by Holocene marine sediments without an intervening till. Such occurrences could be from outside the limit of the Kap Melville advance or be from the post-advance stage of isostatic depression. The tentatively identified pre-Holocene marine benches in Melville Bugt could also be placed in this phase. However until more direct correlation of the deposits is possible such a scheme must be considered to be very hypothetical.

Other glacial episodes have to be fitted into the succession, namely the ice sheet glaciation of Melville Bugt, and Dundas (Krinsley, in Davies et al., 1963); and the younger phases of the Wolstenholme Moraine and the slightly more extensive zone of lightly weathered grey till in Wolstenholme Fjord of Krinsley's. The ice sheet stage at least is presumed to predate the Kap Melville event and be early last glaciation, or older, but the relationship of the younger phases is not known.

\section{Acknowledgements}

I am very grateful to G. Miller of INSTAR, Colorado, U.S.A., for the amino acid determinations and to R. Otlett, Harwell, U.K., for discussion of the ${ }^{14} \mathrm{C}$ data. Assistance with the field work was provided by I. Shaw.

\section{Results \\ ${ }^{14} \mathrm{C}$ samples dated in 1979}

All dates are corrected for isotopic fractionation by normalising to $-25 \%$ PDB. A reservoir correction of 400 years also has been applied to all shell dates. Although this is considered appropriate for central West Greenland (Krog \& Tauber, 1974) its validity for north-western Greenland is not yet established. A $2 \sigma$ above background criterion is used for finite dates and minimum dates are calculated as sample activity $+2 \sigma$. The standard error is an estimate of overall sample reproducability and not just based on counting statistics (Otlett, personal communication).

GGU-194460: HAR-2885

$2810 \pm 70$ B. P., $\delta^{13} \mathrm{C}=-26.1 \%$ 。

Moss peat from the basal $0.06 \mathrm{~m}$ of an $0.9 \mathrm{~m}$ thick peat resting on beach cobbles at $2.85 \mathrm{~m}$ above mean sea level. Niaqornârssuk, Kap York, Thule district. $75^{\circ} 47.5^{\prime} \mathrm{N}, 66^{\circ} 44.9^{\prime} \mathrm{W}$. 
Historical Moraine. Other species present include Astarte sp. and Cardium sp. Sermipaluk glacier, Melville Bugt, Thule district. $76^{\circ} 1.7^{\prime} \mathrm{N}, 65^{\circ} 32.2^{\prime} \mathrm{W}$.

GGU-194468: HAR-2947

$2510 \pm 80$ B. P., $\delta^{13} \mathrm{C}=1.6 \%$

Reworked shell fragments of Mya truncata and Hiatella arctica from the Historical Moraine. Other species present include Cardium sp. Mohn Gletscher, Melville Bugt, Thule district. $76^{\circ} 10^{\prime} \mathrm{N}, 63^{\circ} 44.3^{\prime} \mathrm{W}$.

GGU-194470/71: HAR-2948

$>40400$ B. P., $\delta^{13} \mathrm{C}=1.1 \%$ 。

Shells of Mya truncata and Hiatella arctica from $1.5 \mathrm{~m}$ of clayey silts overlain by $2 \mathrm{~m}$ of coarse boulder till in a low cliff at sea level. Other species present include Chlamys islandicus, Astarte sp. and Balanus balanus. Navdlortoq, Melville Bugt, Thule district. $76^{\circ} 8.2^{\prime} \mathrm{N}$, $64^{\circ} 3.4^{\prime} \mathrm{W}$.

GGU-194478: HAR-2949

$>35500$ B. P., $\delta^{13} \mathbf{C}=0.9 \%$ 。

Shells of Mya truncata from $0.6 \mathrm{~m}$ of fossiliferous sands and gravel overlain by $1.4 \mathrm{~m}$ of till-like clayey sands with boulders. Other species present include Balanus balanus. Ivarqigsorssuaq, Melville Bugt, Thule district. $76^{\circ} 13.2^{\prime} \mathrm{N}, 62^{\circ} 46.4^{\prime} \mathrm{W}$.

GGU-194479: HAR-2950

$7910 \pm 90$ B. P., $\delta^{13} \mathrm{C}=0.9 \%$

Reworked shell fragments largely of Mya truncata and Hiatella arctica from the Historical Moraine. Other species present include Balanus balanus. Døcker Smith Gletscher, Melville Bugt, Thule district. $76^{\circ} 15.9^{\prime} \mathrm{N}, 62^{\circ} 14.2^{\prime} \mathrm{W}$.

GGU-194483: HAR-2955

$7050 \pm 80$ B. P., $\delta^{13} \mathrm{C}=1.7 \%$

Reworked shell fragments of Mya truncata and Hiatella arctica from the Historical Moraine. Other species present include Balanus balanus. Harald Moltke Bræ, Wolstenholme Fjord, Thule district. $76^{\circ} 35.3^{\prime} \mathrm{N}, 68^{\circ} 8.2^{\prime} \mathrm{W}$.

GGU-194484: HAR-2954

$>38000$ B. P., $\delta^{13} \mathrm{C}=\mathbf{0 . 8 \%}$

Shells of Mya truncata and Hiatella arctica from $12 \mathrm{~m}$ of sands and boulders exposed at sea level. Other species present include Macoma calcarea, Serripes groenlandicum, Cardium ciliatum, Chlamys islandicus, Balanus balanus. Wolstenholme Fjord, Thule district. $76^{\circ} 35.1^{\prime} \mathrm{N}, 68^{\circ} 10.5^{\prime} \mathrm{W}$.

\section{References}

Blake, W. 1975: Glacial geological investigations in northwestern Greenland. Pap. geol. Surv. Can. 75-1A, 435-439.

Blake, W. 1977: Radiocarbon age determinations from the Carey Islands, Northwest Greenland. Pap. geol. Surv. Can. 77-1A, 445-454.

Crane, H. R. \& Griffin, J. B. 1959: University of Michigan radiocarbon dates IV. Radiocarbon Supp. Am. J. Sci. 1, 173-198.

Davies, W. E., Krinsley, D. B. \& Nicol, A. H. 1963: Geology of the North Star Bugt area, Northwest Greenland. Meddr Grønland 162(12), 68 pp. 
Dawes, P. R. 1979: Field investigations in the Precambrian terrain of the Thule district, North-West Greenland. Rapp. Grønlands geol. Unders. 95, 14-22.

Goldthwait, R. P. 1960: Study of an ice cliff in Nunatarssuaq, Greenland. Tech. Rep. Cold Reg. Res. Engng Lab. 39, 108 pp.

Krog, H. \& Tauber, M. 1974: C-14 chronology of Late- and Postglacial marine deposits in North Jutland. Danm. geol. Unders. Arbog 1973, 93-195.

Miller, G. H., Andrews, J. T. \& Short, S. K. 1977: The last interglacial-glacial cycle, Clyde foreland, Baffin Island, N. W. T.: stratigraphy, biostratigraphy, and chronology. Can. J. Earth Sci. 14, 2824-2857.

Weidick, A. 1978: Comments on radiocarbon dates from northern Greenland made during 1977. Rapp. Grønlands geol. Unders. 90, 124-128.

Department of Environmental Sciences, University of Lancaster, Lancaster LAI $4 Y Q$,

U.K.

\title{
Field work on Precambrian granites and metasediments in the Søndre Upernavik - Kuvdlorssuaq region $\left(72^{\circ} 00^{\prime}-74^{\circ} 40^{\prime} \mathrm{N}\right)$, northern West Greenland
}

\author{
Jan C. Escher and Ole Stecher
}

The 1979 field work was the last of a series of three GGU reconnaissance mapping expeditions in the Søndre Upernavik - Kuvdlorssuaq region. The investigations aimed at the production of the 1:500 000 geological map sheet of the Mârmorilik - Melville Bugt region. However, at the end of the 1979 field season it became clear that enough field data had been collected for the production of a series of six 1:100 000 geological map sheets covering the region between $72^{\circ} 00^{\prime}$ and $75^{\circ} 00^{\prime} \mathrm{N}$. Support was again provided by the GGU motor cutter $K . J$. V. Steenstrup with Andreas Viðstein as skipper.

To consolidate the work of previous field seasons, time was spent in correlative work and re-investigation of certain areas. Special attention was given to the Prøven charnockite complex and the stratigraphy of the metasedimentary cover. A preliminary general outline of the regional geology was given by Escher \& Stecher (1978).

\section{Prøven charnockite complex}

The youngest major group of rocks of the region is a large belt of hypersthene granite consisting of a variety of granite types. The contacts at the complex are concordant with the major structures of the surrounding gneisses of the basement and cover. These gneisses dip 